\title{
Peranan Komunitas Arab dalam Bidang Sosial-Keagamaan di Betawi 1900-1942
}

\author{
Muhammad Haryono ${ }^{1}$
}

\begin{abstract}
Abstrak
Komunitas Arab-Hadhrami di Betawi peranannya dirasa amat besar bagi masyarakat Betawi, tidak hanya terkenal sejak dahulu keahliannya dalam bidang politik dan perdagangan, namun juga dalam bidang sosial-keagamaan. Wujud nyata dari peranan yang dimainkan oleh orang-orang Arab tersebut terlihat sekali ketika memasuki awal abad XX, yakni dengan didirikannya sebuah organisasi modern yang bergerak di bidang sosial-keagamaan yang bernama Jamiat Kheir. Organisasi ini terkenal bukan saja karena keberhasilannya mendirikan sekolah-sekolah modern dan melahirkan tokoh-tokoh Islam penting, tetapi juga karena kegiatan sosial-keagamaannya yang diwujudkan dalam bentuk pendirian beberapa panti asuhan, Islamic center, majelis taklim, percetakan dan juga fasilitas umum seperti; perpustakaan, masjid, dan rumah sakit. Kegiatan itu pun masih tetap berlangsung hingga kini dalam program kegiatan-kegiatan yang dilaksanakan oleh ar-Rabithah al-Alawiyyah. Fakta ini cukup menjadi suatu bantahan atas pernyataan seorang tokoh Orientalis Barat yakni, L.W.C Van den Berg yang kemudian diikuti oleh kalangan orientalis lainnya seperti K.A Steenbrink dan C. Snouck Hurgronje, yang menyatakan bahwa motivasi utama orang-orang Arab datang ke Nusantara hanyalah untuk berdagang dan mencari keuntungan materi semata. Oleh karena itu, tujuan penilitian ini adalah untuk membuktikan bahwa tidak semua orang-orang Arab yang datang ke Nusantara khususnya di Betawi, bertujuan hanya untuk berdagang dan mencari keuntungan materi semata.
\end{abstract}

Kata Kunci: Arab-Hadhrami, Betawi, Jamiat Kheir, ar-Rabithah alAlawiyyah, L.W.C Van den Berg.

\begin{abstract}
Hadrami Arab community in Batavia felt immense role for the Betawi people, not only famous since ancient expertise in the fields of politics and trade, but also in the socio-religious. Concrete manifestation of the role played by the Arabs was seen once when entering the early twentieth century, namely the establishment of a modern organization that is engaged in socio-religious named Jamiat Kheir. This organization is famous not only for its success establishing modern schools and gave birth to Islamic figures is important, but also because of the socioreligious activities are realized in the form of the establishment of several orphanages, Islamic centers, taklim, printing and also public facilities such as; libraries, mosques, and hospitals. The campaign was still going on today in the program activities carried out by al-Rabita al-Alawiyyah. This fact is quite become a rebuttal to the statement of a prominent Western orientalists namely, LWC Van den Berg followed by the orientalists such as KA Steenbrink and C. Snouck, which states that the primary motivation of the Arabs came to the archipelago are for trade and looking for material gains alone. Therefore, the purpose of this research is to prove that not all Arabs who came to the archipelago, especially in Betawi, aiming only to trade and seek material gains alone.
\end{abstract}

Keywords: Arab-Hadrami, Betawi, Jamiat Kheir, ar-Rabita al-Alawiyyah, L.W.C Van den Berg.

\footnotetext{
${ }^{1}$ SKI FAH UIN Jakarta (Mahasiswa Angkatan 2010)
} 


\section{PENDAHULUAN}

Wilayah kepulauan Indonesia merupakan kawasan yang penting dan strategis, terutama jika dilihat dari aspek ekonomi. Sejarah mencatat, kepulauan Indonesia merupakan daerah yang terkenal sebagai penghasil rempah-rempah terbesar di dunia. Hal tersebut membuat banyak pedagang dari berbagai penjuru dunia datang ke Indonesia untuk membeli rempah-rempah yang akan dijual kembali ke daerah asal mereka. Selain berdagang, adapula para pedagang tersebut berkeinginan untuk mengenalkan agama yang dibawanya kepada penduduk setempat, tanpa terkecuali para pedagang muslim yang berasal dari Arab, Persia, dan Gujarat. Namun sulit untuk menentukan siapa yang pertama kali mengenalkan agama Islam di Indonesia dan juga kapan agama Islam itu pertama kali diperkenalkan.

Menurut pendapat sebagian kalangan orientalis Barat seperti; Pijnappel, Snouck Hurgronje, J.P Moquette, Williem Winstedt, dan S.Q Fatimi, termasuk seorang sejarawan Indonesia yang mendukung Teori Persia yakni, P.A Hoesein Djajadiningrat, bahwa Islam masuk ke Indonesia pada abad XIII $M$ dan yang pertama kali menyiarkannya ialah orang-orang Persia dan India. Pernyataan mereka ini didasarkan pada kesamaan batu nisan makam di Pasai dengan di Gujarat, pesisir Selatan India dan juga kesamaan kebudayaan Syi'ah yang menurutnya masih meninggalkan jejaknya di Sumatera dan Jawa. $^{2}$ Akan tetapi menurut para ahli sejarah dari kaum muslimin, khususnya kaum intlektual muslim di Indonesia, seperti; Azyumardi Azra, Hamka dan Uka Tjandrasasmita, keterangan tersebut sepertinya tidak dapat dibenarkan dan bahkan kuat kemungkinan bahwa hal itu

2 Nur Huda, Islam Nusantara: Sejarah Sosial Intelektual Islam di Indonesia (Jogjakarta: Ar-Ruzz Media, 2007), h. 32-38. memang sengaja dipalsukan untuk tujuantujuan politik penjajahan. ${ }^{3}$

Azyumardi Azra dalam bukunya "Islam Nusantara" menyatakan bahwa, "...Islam di Nusantara dibawa langsung dari Tanah Arab pada Abad ke-VII yang diperkenalkan langsung oleh para guru atau juru dakwah dan orang yang pertama kali masuk Islam adalah para penguasa..."4 Begitupula Uka Tjandrasasmita dalam bukunya "Pertumbuhan dan Perkembangan KotaKota Muslim di Indonesia" ia menduga bahwa, "...Islam datang ke Indonesia pada abad ke-7 dan ke-8. Pada abad ini, dimungkinkan orang-orang Islam dari Arab,

${ }^{3}$ Penulis sependapat dengan ketiga Tokoh tsb. Jika pernyataan sebagian orang Barat bahwa, Islam masuk ke Indonesia pada abad XIII dibawa oleh orang India dan Persia dengan didasarkan pada asumsi kesamaan batu Nisan makam. lantas, apakah pemakainya sudah pasti orang India? Artinya batu Nisan makam boleh saja di datangkan dari India, tetapi belum pasti pemakainya orang India pula, bisa saja di pesan oleh orang lain dari luar India. Adapun pernyataan yang didasarkan pada asumsi kesamaan kebudayaan Syi'ah seperti peringatan Tabut/hari Asyura dibeberapa daerah di Indonesia belakangan ini, Lantas, apakah para pengamalnya sudah pasti mayoritas menganut madzhab Syi'ah? Penulis akui mengenai madzhab Syi'ah pernah masuk dibeberapa wilayah di Nusantara khususnya di Aceh, memang ada buktinya dalam sejarah Indonesia namun, tidak ada kepastian bahwa para pembawa tradisi kebudayaan Syi'ah itu juga mayoritas menganut madzhab Syi'ah. Sebab, dibeberapa daerah di Indonesia kelompok yang menamakan diri kaum Alawiyyin (yang bernasab pada Ahmad al-Muhajir bin Isa) asal Hadramaut yang mayoritas bermadzhab Syafi'i, sering pula melakukan tradisi Syi'ah seperti peringatan hari Asyura atau 10 Muharram namun, dengan bentuk ritual yang berbeda. Hal tersebut dilakukan karena Hasan dan Husein selama ini mereka akui sebagai leluhur mereka. Oleh karena itu, pendapat masuknya Islam ke Indonesia mulai abad XIII M, tentu tidak dapat diterima begitu saja, mengingat orang-orang Islam dari Arab, Persia, dan India sudah banyak berhubungan dengan orangorang di Asia Tenggara dan Asia Timur jauh sebelum abad XIII yakni, pada Abad VII dan Abad VIII seperti yang telah dikemukan di atas oleh Uka Tjandrasasmita. Karena itu lebih tepat abad XIII M dikatakan sebagai masa awal berdirinya kerjaaan yang bercorak Islam, sekaligus menandai perkembangan Islam di Nusantara.

4 Azyumardi Azra, Islam Nusantara: Jaringan Global dan Lokal (Bandung: Mizan, 2002), h. 31. 
Persia, dan India sudah banyak berhubungan dengan orang-orang di Asia Tenggara dan Asia Timur..."5

Pernyataan demikian

semakin memperkuat apa yang dinyatakan sebelumnya oleh Hamka dalam seminar "Sejarah Masuknya Agama Islam di Indonesia" yang diselenggarakan pada 1720 Maret 1963 di Medan. Ia telah menyatakan sekaligus menyimpulkan bahwa, "...Islam masuk untuk pertama kalinya ke Indonesia pada abad pertama Hijriah langsung dari Negeri Arab dan bahwa daerah pertama yang didatangi ialah pesisir Barat Sumatera, tempat terbentuknya masyarakat Islam serta kerjaan Islam pertama..."6

Terlepas dari perdebatan di atas, pada abad-abad tersebut sangat memungkinkan kawasan-kawasan pesisir pantai di Nusantara telah ramai dikunjungi oleh pedagang-pedagang muslim baik itu dari Arab, Persia maupun dari India dan mereka telah membentuk pemukiman-pemukiman khusus di kawasan tersebut. Hal ini sudah menjadi suatu hal yang biasa, lazim dilakukan oleh para pedagang asing apabila datang ke tempat-tempat perdagangan yang berada disekitar kawasan Nusantara, mereka tidak segera kembali ke tempat asal mereka, disamping karena menunggu barang dagangannya habis dan dapat membawa barang dagangan baru penduduk setempat, juga menunggu waktu pelayaran kembali yang bergantung pada musim. Hal ini yang pada akhirnya memaksa mereka untuk bertempat tinggal berbulan-bulan di tanah perantauan. Selama tinggal diperantauan mereka saling berinteraksi dengan penduduk setempat, tidak jarang pula penduduk setempat khususnya kaum bangsawan atau raja-raja berhasrat menikahkan putri-putrinya kepada para pedagang tersebut. khususnya para

${ }^{5}$ Uka Tjandrasasmita, Pertumbuhan dan Perkembangan Kota-Kota Muslim di Indonesia (Kudus: Menara Kudus, 2000), h. 17

${ }^{6}$ A. Hasjmy dan Hussein Azmi, Sejarah Masuk dan Berkembanganya Islam di Indonesia, Cet. I (Bandung: Al-Ma’arif, 1981), h.. 156 dan 195. pedagang Arab yang kaya-raya dan memiliki strata sosial yang tinggi seperti kalangan Sayyid. Akibat perkawinan tersebut, tidak jarang pula kemudian ada yang diangkat dalam susunan birokrasi kerajaan, bahkan diangkat sebagai seorang raja. Hal ini tentunya akan memunculkan sebuah kekuatan politik baru di Kepulauan Nusantara. Oleh karena itu, dalam perkembangan selanjutnya sekitar abad ke$13 \mathrm{M}$ hingga abad ke-16 M, berdirilah beberapa Kerajaan besar bercorak Islam di Nusantara, yang berdirinya pun hampir bersamaan, diawali dengan berdirinya Kerajaan Islam di Sumatera yakni; Pasai (1267-1521), Aceh Darussalam (14961903), Malaka (1402-1511), lalu menyusul di Pulau Jawa berdiri kerajaan Demak (1475-1548), Cirebon (1552-1677), Banten (1524-1813), Pajang (1568-1618), Mataram (1586-1755), di Maluku berdiri kerajaan Ternate (1257-sekarang), Tidore (11101947), Jailolo (1495-1805), Bacan (12841805), di Sulawesi berdiri kerajaan Buton (1332-1911) dan Gowa (abad 16-1667), di Kalimantan berdiri kerajaan Banjar (15261905). ${ }^{7}$

Dengan masuk Islamnya penduduk pribumi Nusantara dan terbentuknya pemerintahan-pemerintahan Islam, tentunya hubungan perdagangan dengan kaum muslimin dari pusat dunia Islam menjadi semakin erat. Orang Arab yang bermigrasi ke Nusantara juga semakin banyak, yang terbesar diantaranya adalah berasal dari Hadramaut, Yaman Selatan. Para perantau Arab-Hadramaut ini mulai datang secara massal ke Nusantara pada tahun-tahun terakhir abad ke-18 M, tetapi mereka mulai banyak menetap di pulau Jawa setelah tahun $1820 \mathrm{M}$ dan koloni-koloni mereka di bagian Timur Nusantara baru tiba pada tahun $1870 \mathrm{M}^{8}$ Menurut statistik tahun $1885 \mathrm{M}$ tercatat jumlah imigran Arab yang

\footnotetext{
${ }^{7}$ Darmawijaya. Kesultanan Islam Nusantara (Jakarta: Pustaka Al-Kautsar, 2010), h. 3-4.

${ }^{8}$ L.W.C Van Den Berg, Le Hadramout et les colonies Arabes dans ,I"Archipel Indien, diterjemahkan oleh Rahayu Hidayat, Hadramaut dan Koloni Arab di Nusantara, Jilid III ( Jakarta:INIS, 1989), h. 72.
} 
menetap di Indonesia mencapai 2.478 Jiwa. ${ }^{9}$ Dalam Tarikh Hadramaut, migrasi ini bahkan dikatakan sebagai yang terbesar sepanjang sejarah Hadramaut.

Perjalanan orang Hadramaut ke Nusantara awalnya dilakukan dengan menumpang kapal kayu. Mula-mula mereka harus ke pelabuhan al-Mukalla atau alSyihr, berlayar ke Malabar di India Selatan, dari sana ke Srilangka, lalu ke Aceh atau Singapura, kemudian menyebar ke Kepulauan Nusantara lainnya. Oleh karenanya, perjalanan mereka untuk sampai ke Nusantara bisa memakan waktu berbulan-bulan. Namun, sekitar tahun 1870an, ketika telah ada jalur lalu lintas kapal uap dari Eropa ke Timur jauh, mereka sebagian lebih memilih menaiki kapal uap tersebut dan langsung menuju ke Kepulauan Nusantara ini dengan mudah dan lebih cepat, walaupun mereka harus membayar lebih mahal. ${ }^{10}$

Kaum perantau ini meskipun tanpa banyak pengetahuan dan keterampilan, mereka dapat hidup wajar dan cepat maju. ${ }^{11}$ Sekitar abad XIX M, muncul orang-orang Hadramaut sebagai pedagang sukses di Palembang dan berbagai negeri pelabuhan di Utara pulau Jawa. ${ }^{12}$ Di Jawa pada umumnya mereka mempunyai pemimpin dari kalangan mereka sendiri yang dikenal dengan sebutan kepala koloni, tanpa terkecuali juga di Betawi. Komunitas Arab di Betawi pada mulanya hanya bertempat tinggal pada wilayah khusus ${ }^{13}$ yakni, Pekojan dan kebebasan bergerak (aktivitas) mereka pun awalnya hanya terkugkung dalam batas-batas tertentu, ini karena kebijakan dari pemerintah kolonial yang sedang berkuasa pada waktu itu yakni, dengan membagi masyarakat Betawi

${ }^{9}$ Van Den Berg, Le Hadramout et les colonies Arabes dans, h. 68-70.

${ }^{10}$ Van Den Berg, Le Hadramout et les colonies Arabes dans, h. 80.

${ }^{11}$ Van Den Berg, Le Hadramout et les colonies Arabes dans, h. 80

12 ANRI: Staadsblad van Nederlandsch-Indie 1816 nomer 47.

13 M. Hasyim Assegaf, Derita Putri-Putri Nabi (Bandung: PT. Remaja Rosdakarya,2000), h. 121. berdasarkan ras atau bangsanya (Wijken Stelsel) di tempat-tempat tertentu dan juga kewajiban membawa surat jalan apabila hendak berpergian (Passen Stelsel). ${ }^{14}$ Akan tetapi dalam perkembangan selanjutnya ketika akan memasuki awal abad ke-20 M, mereka baru bisa bertebaran ke wilayahwilayah lainnya yang berada di Betawi seperti; Krukut, Tanah Abang, Petamburan, Kwitang, Jatinegara, Condet dan sebagainya.

\section{PEMBAHASAN}

\section{A. Persebaran Orang-Orang Arab di Betawi}

Sebagaimana telah diketahui, sejak abad XVIII hingga akhir abad XIX tanah Betawi telah ramai dikunjungi oleh orang-orang Arab yang mayoritas berasal dari Hadramaut. Pada mulanya meraka hidup mengelompok secara sukarela dan mengandalkan berdagang untuk memenuhi kebutuhan hidupnya. Meskipun begitu, tidak serta merta dijadikan pula penilaian bahwa berdagang merupakan motivasi sekaligus tujuan mereka hijrah ke Nusantara. Sebagaimana yang dituduhkan oleh kalangan-kalangan orientalis seperti L.W.C van den Berg. ${ }^{15}$

${ }^{14}$ Hasyim Assegaf, Derita Putri-Putri Nabi, h. 142.

15 L.W.C van den Berg di dalam karyanya yang berjudul: "Le Hadhramout Et. Les Colonies Arabes Dans L" Archipel Indien", Hadramaut dan Koloni Arab di Nusantara, yang diterjemahkan oleh Rahayu Hidayat. Jakarta: INIS, 1989. Pada Jilid ke-3 halaman 79, Ia mengatakan: “...Tak seorang Arab pun tiba di Nusantara hanya untuk bertujuan menyebarkan agama, kalaupun ada di antara mereka yang memegang posisi keagamaan sebagai qadi, imam, ataupun Da'i itu hanyalah untuk mengejar imbalan keuangan yang tidak bermotifkan agama..." Padahal di halaman berikutnya pada halaman 81, Ia mengatakan: "Jarang dijumpai orang Arab, apakah ia kaya atau miskin, yang membelanjakan seluruh pendapatannya. Menabung merupakan budaya bagi mereka dan fakta bahwa mereka pernah menikmati kemakmuran. Perlu pula dikatakan dengan angkat topi, bahwa begitu mereka menjadi kaya di Nusantara, mereka hampir tidak pernah melupakan anggota keluarga mereka di tanah air. Apabila mereka tidak membutuhkan bantuan, orang Arab itu akan menyumbangkan kelebihan uangnya kepada 
Memang tidak bisa dinafikan pula, sebagian dari mereka nyatanya ada yang bertujuan demikian, terlebih lagi dari kalangan Qabili yang merupakan kelompok mayoritas. Hal ini dikarenakan ketika itu orang-orang Arab yang datang ke Nusantara terdiri dari beberapa golongan ataupun lapisan sosial:

1. Golongan Sadah (Jamak dari Sayyid yang artinya tuan) yaitu, golongan tertinggi dan terpandang yang merupakan nigrat keagamaan. Golongan ini menganggap dirinya sebagai keturunan cucu-cucu Nabi Muhammad SAW, dari pernikahan putri Nabi yang bernama Fatimah dengan Ali bin Abi Thalib, dan umumnya golongan sadah

mesjid, sekolah atau ke yayasan keagamaan lain, bahkan ada yang mengirimkan uangnya kepada cedikiawan yang mereka hormati atau kepada sahabat yang lanjut usia.”. Kemudian pada halaman 84 dan 87 Ia juga mengatakan: “...Orang Arab tidak menyukai kemewahan baik di dalam rumah maupun di luar rumah. Seorang Arab yang telah memperoleh kekayaan jarang meneruskan usahanya dengan semua yang diperolehnya. Pada diri orang Arab tidak ada keinginan menjadi mulia seperti orang Eropa yang mendirikan rumah dagang besar yang tetap bereputasi baik meskipun para pendirinya sudah mengundurkan diri..." Inilah bukti kekeliruan van den Berg dalam memahami kehidupan orang-orang Arab ketika itu. Oleh karenanya menurut asumsi Penulis bahwa hal tersebut memang tidak terlepas dari kedudukannya sebagai pegawai pemerintah kolonial, dimana tugas mereka adalah berusaha menghilangkan pengaruh Arab (Islam) dari masyarakat pribumi guna mempertahankan jajahannya di bumi Nusantara. Selain itu penulis juga menduga kenapa mereka berpandangan demikian, hal ini karena kurangnya pengetahuan mereka tentang konsep dagang Islam, serta latar belakang budaya dan mentalitas bangsa Arab, sehingga mereka sulit untuk menditeksi misi yang tersirat di balik fenomena yang tampak dihadapan mereka. Sebagaimana yang pernah dinyatakan oleh Pak Alwi Shahab dalam bukunya yang berjudul "Islam Inklusif: Menuju Sikap Terbuka dalam Beragama” (Bandung: Mizan, 1998) h. 323-324, maupun artikel-artikel yang pernah ditulisnyadi dalam media massa, seperti yang terdapat dalam koran harian Republika, yang diterbitkan pada hari Jum'at, 22 September 1995. h. 8. Menurutnya, Bahwa kekeliruan Van den Berg, dkk dalam memahami kehidupan orang-orang Arab disebabkan oleh 3 faktor: 1) kurangnya pengetahuan tentang konsep dagang Islam. 2) latar belakang budaya 3) dan mentalitas bangsa Arab. dari Hadhramaut berasal dari keturunan Husain bin Ali bin Abi Thalib. Lalu mengapa golongan sadah mendapat gelar Sayyid atau Syarif dan untuk Prempuannya Syarifah. Menurut Yasmin Zacky Shahab dalam Skripsinya yang berjudul "Masalah Integrasi Minoritas Arab di Jakarta”, mengatakan:

"Hadramaut dahulu yang
merupakan tanah asal

kebanyakan golongan sadah di Jakarta, hampir tidak ada yang bekerja dalam bidang perdagangan dan industri, juga tidak ada dari mereka yang menjadi petani. Mereka lebih pada memegang peran dalam bidang keagamaan dan pemerintahan yang dianggap sebagai suatu kedudukan yang terhormat. Oleh karena itu mereka mendapat penghormatan dalam masyarakatnya dengan sebutan "Tuan" atau "orang yang terhormat", hal demikian berjalan terus sampai turun temurun." 16

Hal ini pun diperkuat oleh pendapat Husain Haikal dalam desertasinya yang berjudul "Indonesia-Arab dalam Pergerakan Kemerdekaan Indonesia (19001942).” mengatakan, “...Memang sebagian dari golongan sadah dikenal sebagai orang yang sangat dalam ilmu agamanya, bahkan dapat dikatakan mereka hampir memonopoli dalam berbagai bidang ilmu yang berada di Hadramaut, sehingga untuk bekerja yang sifatnya memerlukan tenaga, jarang mereka lakukan, apabila mereka

16 Yasmin Zacky Shahab , "Masalah Integrasi Minoritas Arab di Jakarta," (Skripsi Sarjana Antropologi Fakultas Sastra, Universitas Indonesia Jakarta, 1975), h. 86. 
terpaksa harus bekerja. Mereka hanya jadi pengawas saja..."

Di beberapa tempat khususnya di Indonesia. Golongan sadah ini mendapatkan panggilan yang berbeda-beda. Mereka ada yang di panggil dengan sebutan Sayyid, Syarif, Habib, wan, Ami, sebagaimana yang penulis amati sendiri di lapangan. Dalam kesehariannya, golongan ini juga sering menyebutkan dirinya sebagai Ba'alwi atau Bani Alawi yakni sebuah nama yang dinisbahkan kepada seorang tokoh yang bernama Alwi bin Ubaidillah bin Ahmad al-Muhajir bin Isa bin Muhammad bin Ali al-Uraidhi bin Ja'far ash-Shaddiq bin Ali Zainal Abidin bin Husein bin Ali Suami Fatimah binti Rasulullah SAW. Awalnya sebutan Alawi sendiri diberikan kepada semua keturunan Ali bin Abi Thalib, baik dari anaknya yang bernama Hasan maupun Husein, namun selanjutnya, sebutan Alawi hanya digunakan untuk keturunan Alwi bin Ubaidillah dari garis keturunan Husein. ${ }^{18}$ Hal ini untuk membedakan dari keluarga para Sayyid yang sama-sama keturunan Rasulullah SAW.

2. Golongan Masyayikh (Jamak dari Syaikh yang berarti orang tua atau orang yang beriman). Istilah Syaikh sendiri sebenarnya hanya sebuah gelar kehormatan bagi semua orang yang mengabdikan diri dalam ilmu pengetahuan, khususnya dalam bidang keagamaan. Tetapi ada dua suku dan beberapa family qabili warga Hadramaut yang berhak menggunakannya sebagai gelar warisan, yakni Suku Baraik dan Suku Amudi. Family yang menggunakan gelar Syaikh khususnya yang terdapat di Indonesia adalah Bafadhel (keturunan ahli hukum

\footnotetext{
${ }^{17}$ Husein Haikal, "Indonesia-Arab dalam Pergerakan Kemerdekaan Indonesia (19001942),”(Desertasi Phd, Univesitas Indonesia Jakarta, 1986), h. 54.

${ }^{18}$ Idrus Alwi al-Masyhur, Sejarah, Silsilah dan Gelar Keturunan Nabi Muhammad SAW di Indonesia, Singapura, Malaysia, Timur Tengah, India dan Afrika (Jakarta, Saraz Publishing, cet. 2. 2010), h. 101-102.
}

dan teologi terkenal), Bahmid, Baraja, Baharmi, Bawajir, Basyu'aib, Bamuzahmi, Ba'abbad, Bin Khathib, alZabda. ${ }^{19}$ Jadi gelar Syaikh itu hanya semata-mata gelar kehormatan, tanpa suatu hak Istimewa, dan juga tidak mesti berarti pemakainya merupakan kalangan family terpelajar. Dahulu sebelum golongan sadah datang ke Hadramaut. Golongan inilah yang memegang peranan dalam bidang keagamaan, akan tetapi setelah golongan sadah datang ke Hadramaut, kedudukan golongan ini terdesak dan bahkan golongan sadah berhasil memonopoli semua kegiatan yang berkaitan dengan ilmu agama. ${ }^{20}$

3. Golongan Qaba'il (Jamak qabili yang berarti Suku atau "gerombolan") adalah golongan ningrat duniawi. menurut G.F Pijper, kaum qabili ini merupakan mayoritas penduduk Hadramaut. Pada abad ke-19, jumlahnya terdapat 17 suku di Hadramaut, selain itu, menurutnya ada pula dua suku besar dan penting karena kekuasaannya di Hadramaut. Pertama, Suku al-Syanfari. Suku ini terdiri dari berbagai anak suku. Kepala dari semua keturunan al-Syanfari adalah sultan Sei'un. Ia Muhammad bin Syanfari al-Hamdani, yang menurut lagenda merupakan raja pertama di Hadramaut. Kedua, suku al-Yafi, keturunan Yafi bin Himyar. Suku ini terbagi dalam tiga anak suku dan family al-Qa'aithi merupakan kepala suku Yafi yakni, penguasa al-Syihr dan beberapa kota lain. ${ }^{21}$

${ }^{19}$ G.F Pijper, Studien over de Geschiedenis van de Islam in Indonesia 1900-1950, Terjemahan, Tudjimah dan Yessy Augusdin, Beberapa Studi tentang Sejarah Islam di Indonesia 1900-1950, h. 21.

${ }^{20}$ L.W.C Van Den Berg, Le Hadramout et les colonies Arabes dans „I"Archipel Indien, diterjemahkan oleh Rahayu Hidayat, Hadramaut dan Koloni Arab di Nusantara, h. 28.

${ }^{21}$ G.F Pijper, Studien over de Geschiedenis van de Islam in Indonesia 1900-1950, Terjemahan, Tudjimah dan Yessy Augusdin, Beberapa Studi 
4. Golongan Da'fa (Jamak dari dhaif), merupakan sebuah kelompok yang terdiri dari orang-orang merdeka yang tinggal di kota-kota dan desa, yang bukan anggota suatu suku dan tidak pula termasuk Syaikh ataupun Sayyid. Mereka terdiri dari para pedagang, tukang, pengrajin, buruh, dan pelayan. Mereka dipandang sebagai kalangan rendah, setingkat di atas para budak.

5. Golongan Abid (Jamak dari abd yang artinya hamba atau budak), di Hadramaut pada umumnya kaum budak ini berasal dari Somalia dan Nudia, yang pada kemudian kebanyakan lahir di Hadramaut. Nasib mereka disana sama sekali tidak sama dengan budakbudak yang berada di Eropa dan Amerika, yang dipekerjakan dengan paksa, bahkan dirantai. Karena ketentuan hukum Islam mereka di Hadramaut diperlakukan sebagai anggota rumah tangga. budak-budak Hadramaut semuanya beragama Islam. Mereka tidak memakai nama family, tetapi biasanya memakai julukan. Banyak diantara keturunan bekas budak yang kemudian merantau ke berbagai tempat termasuk ke Nusantara. ${ }^{22}$

Diantara ke lima golongan di atas dalam hubungannya dengan aktivitas dakwah Islamiyah di Nusantara khususnya di Betawi ialah golongan Sayyid dan golongan Syaikh, keduanya banyak memainkan peran dalam bidang keagamaan,tetapi golongan Sayyid jauh lebih menonjol ketimbang golongan Syaikh. ${ }^{23}$ Para Sayyid sangat dihormati bukan hanya karena dipandang keturunan Nabi yang sudah selayaknya menerima penghormatan, melainkan juga

tentang Sejarah Islam di Indonesia 1900-1950, h. 23-27.

${ }^{22}$ L.W.C Van Den Berg, Le Hadramout et les colonies Arabes dans „I“Archipel Indien, diterjemahkan oleh Rahayu Hidayat, Hadramaut dan Koloni Arab di Nusantara, h. 47

${ }^{23}$ Abdul Aziz. Islam dan Masyarakat Betawi (Jakarta: PT. Logos Wacana Ilmu. 2002), h. 144. karena mengingat jasa kelompok ini yang sejak lama sudah terkenal sebagai penyebar Islam dan sumber kader ulama. ${ }^{24}$ Hal ini sesuai dengan apa yang dinyatakan oleh Van den Berg dalam bukunya yang berjudul "Le Hadramout et les colonies Arabes dans „I"Archipel Indien” yang dikutip sekaligus diterjemahkan oleh Alwi bin Thahir AlHaddad. Ia mengatakan, “...Adapun hasil nyata dalam penyebaran agama Islam adalah dari para Sayyid/Syarif. Dengan perantara mereka tersebarlah Islam di antara para sultan-sultan Hindu di Jawa dan yang lainnya. Walaupun ada orang-orang Arab Hadramaut selain mereka, mereka tidak mempunyai pengaruh seperti itu. Hal ini disebabkan karena mereka adalah keturunan dari pembawa ajaran Islam (Nabi Muhammad)...,25

Sebagaimana telah diketahui bahwa, para Sayyid di Betawi hampir tidak ada yang bekerja dalam bidang perdagangan dan industri, juga tidak ada dari mereka yang menjadi petani. Mereka lebih pada memegang peran dalam bidang keagamaan dan pemerintahan yang dianggap sebagai suatu kedudukan yang terhormat, kalau pun ada mereka hanya jadi tuan tanah atau pengawas saja. dan hanya orang Arab peranakan yang mau mengerjakan pekerjaan tangan. ${ }^{26}$ Berbeda dengan anggota suku lainnya yang tidak segansegan menjadi pedagang eceran atau penjaja sekali pun. Anggota qabili gemar mengumpulkan uang di tempat rantauan, setelah uangnya terkumpul walaupun dengan jumlah yang tidak begitu banyak mereka segera kembali ke tanah asalnya Hadramaut, begitu uangnya habis mereka mulai lagi dengan prosedur yang sama. ${ }^{27}$ Sedangkan sebagian besar orang Arab di

${ }_{24}$ Abdul Aziz. Islam dan Masyarakat Betawi, h. 39

25 Alwi Bin Thahir Al-Haddad, Sejarah Masuknya Islam di Timur Jauh (Jakarta: PT. Lentera Basritama. Cet. 3. 1997), h. 52.

26 M. Hasyim Assegaf, Derita Putri-Putri Nabi (Bandung: PT. Remaja Rosdakarya, 2000), h.135.

${ }^{27}$ L.W.C Van Den Berg, Le Hadramout et les colonies Arabes dans „I"Archipel Indien, diterjemahkan oleh Rahayu Hidayat, Hadramaut dan Koloni Arab di Nusantara, h. 123. 
Nusantara adalah anggota suku (qabili) disusul golongan menengah kecil dan Sayyid. ${ }^{28}$ Oleh karena itu, menurut analisa penulis bahwa, "tidak semua orang Arab yang datang ke Nusantara itu, hanya bertujuan untuk berdagang ataupun untuk mencari keuntungan materi semata. "29

Orang-orang Arab ini kemudian membentuk koloni diberbagai kota di Indonesia, salah satunya di Batavia atau lebih tepatnya di wilayah Pekojan. Awalnya tempat ini di dominasi oleh umat muslim yang berasal dari Gujarat, Coromandel, dan Malabar, yang terletak di India. Namun, karena semakin banyak pendatang Arab dari Hadramaut, -apalagi ketika telah adanya transportasi kapal uap dan dibukanya terusan suez 1869 M-, tempat ini kemudian menjadi di dominasi oleh para pendatang yang berasal dari Hadramaut. oleh karena itu pada tahun $1844 \mathrm{M}$ pemerintah Hindia-Belanda mengharuskan adanya kepala koloni, yang ketika itu dinamai kapiten atau kapten Arab atau Leuitenant Arab. kepala koloni ini dipilih oleh Bupati setempat dan pengangkatannya dilakukan oleh Residen berdasarkan pertimbangan penasehat urusan dalam negeri.

Pertimbangan dalam pengangkatan kepala koloni diantaranya adalah harus seorang yang dikenal baik di kalangan pemerintah setempat maupun di kalangan orang Arab itu sendiri, kemudian status ekonominya baik dan yang terpenting dapat diajak bekerjasama dengan pemerintah. Adapun tugas dari kepala koloni tersebut adalah memberi penjelasan mengenai

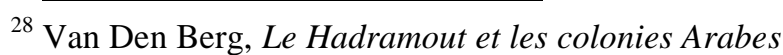
dans, h. 91.

${ }^{29}$ Mengambil teori Max Weber di dalam bukunya, Die Protestantische Ethik und der Geist des Kapitalismus, "Etika Protestan dan Semangat Kapitalisme", diterjemahkan oleh Yusup Priyasudiarja, (Surabaya: Pustaka Promethea, 2000) h. 158-159. Ia mengatakan: “...tingkah laku ekonomi sangat dipengaruhi oleh ajaran agama...". Jadi jelas bahwa perilaku ekonomi para pendatang Hadhrami itu sangat dipengaruhi oleh latar belakang agamanya dan Van den berg penulis rasa tidak memahami hal ini. keputusan dan aturan-aturan yang dikeluarkan oleh pemerintah kepada masyarakat Arab. selain itu juga memberikan data-data yang dibutuhkan oleh Pemerintah Hindia-Belanda terkait dengan kependudukan orang-orang Arab di Nusantara. $^{30}$

Meski wilayah Betawi-Pekojan baru pada tahun $1844 \mathrm{M}$ dihuni oleh kelompok Hadhrami, tetapi dikarenakan ketika itu menjadi tempat transit, maka populasinya berkembang dengan cepat, dengan sentral koloninya di wilayah Krukut, Petamburan, dan Tanah Abang, tentunya dengan dibawah pengawasan yang ketat pemerintah kolonial Hindia-Belanda. Barulah sampai pada penghapusan system pemukiman pada tahun 1919 M, sebagian besar orang Arab di Pekojan yang sebelumya juga ada yang tinggal di Krukut, Petamburan, dan Tanah Abang, kemudian menyebar ke daerahdaerah sekitarnya seperti; Sawah Besar, Jatinegara, Tanah Tinggi, dan Condet. Sekarang hampir tidak tersisa orang Arab di Pekojan, orang-orang Cina lah menjadi penduduk mayoritas disana.

\section{B. Terbentuknya Komunitas Arab di Betawi}

Kata komunitas (Community) berasal dari kata latin communire (Communion) yang berarti memperkuat. Dari kata ini dibentuk istilah communitas yang artinya persatuan, persaudaraan, umat/jemaat, kumpulan bahkan masyarakat. ${ }^{31}$ Menurut Selo Soemardjan sebagaimana yang dikutip oleh Soerjono Soekanto, Ia mengatakan "...Komunitas adalah masyarakat yang bertempat tinggal disuatu wilayah (dalam arti geografis) dengan batas-batas tertentu dimana faktor utama yang menjadi dasar adalah interaksi yang lebih besar diantara para anggotanya, di bandingkan dengan

${ }^{30}$ Julianri, "Persatuan di kalangan Masyarakat Arab Indonesia," (Skripsi Sarjana Sastra Jurusan Sejarah Fakultas Sastra, Universitas Indonesia Jakarta, 1987), h. 13-14.

${ }^{31}$ D. Hendropuspito, Sosiologi Sistematik (Yogyakarta: Penerbit Kanisius, 1989), h. 56. 
penduduk di luar batas wilayah..." 32 Adapun yang menjadi ciri khas dari sebuah komunitas adalah adanya kesatuan hidup yang teratur, tetap dan bersifat territorial, serta memiliki unsur tanah daerah yang sama dimana tempat kelompok itu berada. ${ }^{33}$

Dari penjelasan diatas, maka dapat dimengerti bahwa komunitas adalah kesatuan hidup manusia yang menempati suatu wilayah tertentu yang terikat rasa identitas bersama, dan saling berinteraksi antara satu dengan yang lainnya tentunya untuk mencapai tujuan bersama. Kaitannya dengan komunitas Arab di Betawi, bahwa pada awalnya mereka datang ke Betawi secara bertahap tidak sekaligus, mengikuti kondisi sosial dan politik negaranya, ada yang datang sendiri-sendiri dengan menumpang kapal yang sedang melakukan pelayaran dan juga ada yang secara rombongan. Umumnya mereka datang dengan tidak membawa Istri atau anak-anak mereka, hal ini karena letak kepulauan Nusantara yang begitu jauh dengan daerah asal mereka dan hanya bisa ditempuh melalui jalur laut dengan menggunakan kapal layar, sehingga sangat beresiko bagi Istri atau anak-anak mereka jika mereka membawanya. Oleh karenanya hanya kaum laki-laki saja memberanikan diri hijrah ke Nusantara.

Puncak dari migrasi mereka yaitu, pada akhir abad ke-19 M. Mayoritas dari mereka adalah berprofesi sebagai pedagang dan sebagian kecil dari mereka ada yang merangkap sebagai juru dakwah. Setelah sampai di tempat tujuan, sebagaimana layaknya para pedagang, mereka tidak segera kembali ke tempat asal mereka, disamping karena harus menunggu barang dagangannya habis dan dapat membawa barang dagangan baru, juga menunggu waktu pelayaran kembali yang bergantung pada musim. Hal ini yang pada akhirnya memaksa mereka untuk bertempat tinggal berbulan-bulan di tanah perantauan.

\footnotetext{
32 Soerjono Soekanto, Sosiologi Suatu Pengantar (Jakarta: PT. Grafindo Persada, 2006), h. 133.

${ }^{33}$ D. Hendropuspito, Sosiologi Sistematik, h. 57.
}

Selama tinggal diperantauan mereka saling berinteraksi dengan penduduk setempat, tidak jarang pula penduduk setempat yang pada akhirnya berhasrat menikahkan putri-putrinya kepada para perantau tersebut. Khususnya para pedagang Arab yang kaya-raya dan memiliki strata sosial yang tinggi seperti kalangan Sayyid. Dari pernikahan pasangan campuran ini lahirlah anak-anak keturunan Arab campuran yang disebut dengan peranakan Arab atau muwalad. dengan lahirnya anak-anak peranakan ini maka semakin bertambah banyak orang-orang Arab di Nusantara khususnya di Betawi, sehingga pemerintah kolonial mengeluarkan sebuah peraturan yang mengharuskan setiap warga asing menempati tempat-tempat yang sudah ditentukan berdasarkan ras dan bangsanya. Begitupun juga aturan yang mewajibkan membawa surat apabila hendak berpergian. Dengan adanya peraturan seperti ini, orangorang Arab yang sebelumya mereka hanya menikahi wanita-wanita pribumi, mereka beralih menjadi menikahi wanita-wanita dari etnis mereka sendiri, terutama terjadi pada keturunan pernikahan campuran generasi mereka. Maka bertambah besarlah jumlah mereka dan bertambah besar pula rasa kekerabatan mereka.

Berdasarkan sensus yang diadakan pertama kali secara eksplisit tahun $1859 \mathrm{M}$, menyebutkan di keresidenan Batavia terdapat 312 orang Arab, sebagian besar tinggal di kota. Kemudian, pada tahun 1870 $M$ jumlah mereka naik tiga kali lipat menjadi 952 orang. ${ }^{34}$ Lima belas tahun kemudian tepatnya pada tahun $1885 \mathrm{M}$, keresidenan Batavia menampung 1.662 orang Arab, 1.175 diantaranya lahir di Hindia-Belanda. ${ }^{35}$ Kemudian, diantara rentang tahun $1900 \mathrm{M}$ sampai dengan 1930 $\mathrm{M}$ telah terjadi peningkatan kembali yang

\footnotetext{
${ }^{34}$ Lihat Regeerings Almanak tahun 1859 dan 1870.

${ }^{35}$ L.W.C Van Den Berg, Le Hadramout et les colonies Arabes dans „I"Archipel Indien, diterjemahkan oleh Rahayu Hidayat, Hadramaut dan Koloni Arab di Nusantara, h. 68.
} 
sangat signifikan, bertambah dari 2.245 menjadi 5.231 orang Arab. ${ }^{36}$

Dengan melihat sensus diatas yang di mulai dari tahun $1859 \mathrm{M}$ hingga tahun 1930 $\mathrm{M}$, dengan jumlah yang terus meningkat dan juga semakin besarnya rasa kekerabatan mereka, hal ini menunjukan bahwa minoritas Arab telah berkembang menjadi sebuah komunitas yang mapan, bahkan dari segi jumlah telah mengungguli minoritas Arab di Surabaya, yang sebelumnya merupakan komunitas Arab terbesar di Nusantara.

\section{Peranan Orang-Orang Arab di Betawi 1900-1942}

\section{Dalam Bidang Sosial}

Peranan orang-orang Arab di Betawi dalam bidang sosial sudah ada sejak pertama kali mereka menginjakan kakinya disini, namun sifatnya lebih dan diarahkan kepada misi keagamaan. Salah satu buktinya adalah dengan adanya pendirian langgar, mushala ataupun masjid-masjid yang hingga sekarang bangunannya masih berdiri kokoh dan dapat kita saksikan, meskipun telah mengalami beberapa kali renovasi, namun beberapa bagian penting dari bangunan tersebut keasliannya masih tetap terjaga. Salah satu contohnya ialah masjid Luar Batang yang berdiri pada tahun 1739 M. Masjid yang terletak di tengah perkampungan bernama Luar Batang, Jakarta Utara ini, dahulunya merupakan sebuah mushalah yang digunakan selain tempat ibadah shalat, juga digunakan masyarakat setempat ataupun luas untuk menanyakan berbagai macam permasalahpermasalahan, baik yang berkenaan dengan masalah keagamaan ataupun sosial. Bukan hanya itu saja masjid ini pun digunakan sebagai salah satu tempat persinggahan orang-orang yang hendak melaksanakan ibadah haji dan pulang haji sebelum mereka

\footnotetext{
${ }^{36}$ Kees Grijns and Peter J.M. Jakarta Batavia: SocioCultural essay, Terj. Gita Widya Laksmini dan Noor Cholis, h. 153.
}

kembali ke tempat tinggalnya masingmasing. ${ }^{37}$

Masjid ini karena sering ramai dikunjungi para peziarah dan sering terkena banjir karena letaknya di pinggir pantai, kemudian masjid ini direnovasi dengan diperluas dan ditinggikan lantainya. Karena itu proporsi bangunannya sedikit menghilang.

Selanjutnya peranan orang-orang Arab dalam bidang sosial-keagamaan terlihat sekali ketika memasuki awal abad ke-20 M, yakni dengan didirikannya sebuah organisasi modern yang bernama Jamieeat Kheir, tahun 1905 M. Organisasi ini terkenal bukan saja karena keberhasilannya mendirikan sekolah-sekolah Islam modern, tetapi juga karena kegiatan-kegiatan sosial yang bersifat keagamaan, terutama ketika beberapa Tokoh dari organisasi ini berinisiatif mendirikan sebuah Lembaga khusus yang bernama ar-Rabithah alAlawiyyah. Lembaga ini berdiri pada tahun 1928 M atas prakarsa Sayyid Ahmad bin Abdullah Assegaf dan Sayyid Muhammad bin Abdurrahman bin Ali bin Shahabuddin. Lembaga ini didaftarkan kepada pemerintah Hindia-Belanda dan tercatat dalam akte Notaris Mr. A.H. Van Ophuijsen No. 66 tanggal 16 Januari 1928. kemudian disahkan pemerintah Belanda pada tanggal 27 Desember 1928 M yang ditandatangani oleh G.R. Erdbrink seorang sekretaris pemerintah Hindia-Belanda. ${ }^{38}$

Tujuan dan maksud didirikannya arRabithah al-Alawiyyah sangatlah jelas yakni, berbuat ihsan dan menyeru kepada keridhaan ar-Rahman. Hal ini sebagaimana yang tertuang dalam Ad/ART ar-Rabithah al-Alawiyyah yakni:

1. Memajukan suku Hadhrami baik dari segi moral maupun material.

\footnotetext{
37 Jamroni, “Masjid Bersejarah di Jakarta, ” Jurnal AlTuras Vol. 12 No.2, Fakultas Adab dan Humaniora (Jakarta: UIN Syarif Hidayatullah, 2006), h. 103.

38 Yayasan ar-Rabithah al-Alawiyyah. "80 Tahun Daarul Aitam; Mengelola Anak "Titipan" Rasulullah SAW," (Jakarta: Yayasan ar-Rabithah alAlawiyah Daarul Aitam. 2011), h.17.
} 
2. Memperkuat ikatan persaudaraan diantara golongan Alawiyyin khususnya dan orang-orang Hadhramaut umumnya dan memelihara segala sesuatu yang ada kaitannya dengan mereka.

3. Melaksanakan pencatatan nasab golongan Alawiyyin.

4. Mendidik anak-anak yatim dan membantu janda-janda, orang-orang lemah, menolong fakir miskin, dan orang-orang yang tidak dapat mencari nafkah.

5. Menyiarkan ajaran-ajaran Islam, ilmu-ilmu, Bahasa Arab dan bahasabahasa lainnya.

6. Mengusahakan segala sesuatu yang dapat memakmurkan dan mengamankan Tanah Air dan Negeri Hadramaut.

7. Menerapkan hukum-hukum syariat, menyebarkan ilmu pengetahuan dan segala sesuatu yang dapat mendatangkan kebaikan bagi Tanah Air. $^{39}$

Lembaga ar-Rabithah al-Alawiyyah tidak hanya terdapat di Jakarta saja, tetapi juga tersebar di berbagai daerah di Indonesia dan juga di negara-negara lain. Lembaga ini telah melakukan berbagai macam kegiatan-kegiatan di Masyarakat. Sebagaimana yang tercatat di dalam ikhitisar kegiatan-kegiatan ar-Rabithah alAlawiyyah diantaranya:

1. Memberikan bantuan dalam pendirian Partai Sarikat Islam.

2. Menghimpun dana dalam berbagai kegiatan dan panitia untuk amalamal sosial, diantaranya dalam bentuk pembangunan masjid dan rumah sakit di Jakarta.

3. Membentuk panitia palang merah bagi orang-orang yang tertimpah becana seperti; untuk korban bencana perang dunia II, korban bencana Palestine dan Merapi.

39 Koleksi Pribadi Ali Abu Bakar Shahab, "arRabithah al-Alawiyyah,” (Batavia: T.pn.,1928), h. 2-4.
4. Membentuk panitia peringatan Maulid Nabi SAW tahunan.

5. Membentuk panitia guna memerangi riba dan prostitusi di masyarakat.

6. Mendirikan lembaga khusus bagi kaum wanita yang bernama arRabithah al-Alawiyyat, yang bertujuan untuk memberikan ceramah-ceramah agama, memberantas buta huruf dan melatih kejujuran.

7. Mendirikan sekolah-sekolah, perpustakaan umum, percetakan dan lainnya

8. Membagi-bagikan buku-buku sekolah sebanyak 5400 buah ke 50 madrasah Islamiyyah di seluruh pelosok Indonesia.

9. Membentuk kelompok gerakan pramuka diberbagai kota besar di Indonesia.

10. Mendirikan rumah khusus bagi anak yatim-piatu yang tersebar diberbagai daerah di Indonesia. ${ }^{40}$

Usaha atau kegiatan-kegiatan arRabithah al-Alawiyyah di atas tidak senantiasa berjalan mulus, banyak hambatan-hambatan yang menghalanginya. Lembaga ini sempat mengalami masa-masa krisis yakni, ketika Jepang mulai menjajah negeri ini. Ketika itu ar-Rabithah nyaris tak dapat melangkah sebagaimana biasanya, usaha ar-Rabithah sangat terbatas pada lingkup yang sempit sekali. Penjajah Jepang ketika itu banyak merugikan sekolahsekolah khususnya sekolah yang didirikan oleh ar-Rabithah al-Alawiyyah sehingga tidak dapat berkembang. Begitupun dengan perpustakaan umum yang didirikannya, banyak koleksi kitab-kitab yang hilang, entah karena diambil ataupun dibuang oleh pihak penjajah, seandainya pihak penjaga perpustakaan ketika itu tidak segera menyembunyikan sebagian kitab, niscaya tidak akan tersisa lagi sekarang. Selain itu juga penjajah telah menganggu hubungan harmonis yang sudah ada antara lembaga di

\footnotetext{
40 Koleksi Pribadi Ali Abu Bakar Shahab, "arRabithah al-Alawiyyah,", h. 23-26.
} 
pusat dan cabang-cabangnya. Suasana ketika itu sangat benar-benar sangat kacau dan goncang, sehingga hampir saja sebagian cabang-cabang dan perwakilanperwakilannya nyaris bubar. Namun untungnya lembaga ini masih tetap kuat menjaga kelangsungan hidupnya dan senantiasa berusaha menunaikan amanah yang diembannya. ${ }^{41}$

\section{Dalam Bidang Keagamaan}

Sebagaimana telah diketahui, bahwa kedatangan orang-orang Arab ke Nusantara tidak semata-mata hanya bertujuan untuk mencari keuntungan materi semata salah satunya dengan bergelut di dunia perdagangan seperti yang dituduhkan oleh beberapa kalangan orientalis. Namun ada beberapa komponen masyarakat Arab terutama dari kalangan ulama seperti Syaikh, Sayyid atau Habaib datang secara khusus untuk mendakwahkan Islam kepada peduduk Nusantara. Di Batavia ada beberapa ulama cukup terkenal asal Hadramaut yang secara khusus bergelut di dalam bidang dakwah Islamiyah. Diantaranya adalah Sayyid Husain bin Abu Bakar al-Aidrus, yang wafat pada tahun 1756 M. Ia adalah seorang alim ulama yang semasa hidup senantiasa mengamalkan ilmunya kepada masyarakat khususnya masyarakat Betawi. Melalui sebuah mushalah kecil yang didirikannya pada tahun $1739 \mathrm{M}$ di wilayah yang kini bernama kampung kramat Luar Batang, di sini ia mengenalkan ajaran agama Islam kepada masyarakat Betawi dan menghabiskan masa hidupnya hanya untuk mengamalkan ilmunya kepada masyarakat. $^{42}$

Kemudian ada Syaikh Salim bin Abdullah bin Saead bin Sumair alHadhrami, yang wafat pada tahun $1854 \mathrm{M}$. Ia adalah seorang ahli figh dan tasawuf yang bermadzhab Syafi,,i, yang juga

41 Koleksi Pribadi Ali Abu Bakar Shahab, "arRabithah al-Alawiyyah, ", h. 26-27.

42 Huub De Jonge and Nico Kaptein, Trancending Borders: Arabs, Politics, Trade and Islam in Southeast Asia (Leiden: KITLV Press, 2002), h. 185. terkenal sebagai seorang qadi yang adil, seorang pendidik yang sangat ikhlas dan penyabar. Melalui kitabnya yang terkenal yang diberi nama Safinatun Najah Fiima Yajibu ,ala Abdi li Maulah, ${ }^{43}$ tersyiarlah ajaran agama Islam hingga sampai saat ini. Kemudian pada masanya ada pula seorang ulama asal Hadhramaut yang sengaja datang ke Betawi pada tahun $1823 \mathrm{M}$ hanya untuk menyiarkan ilmunya lalu kembali lagi ke Hadramaut pada tahun 1853 M. Ia adalah Sayyid Abdurrahman bin Abu Bakar al-Habsyi. ${ }^{44}$

Kemudian di tahun-tahun berikutnya datang pula saudagar-saudagar kaya yang diantara mereka merangkap sebagai $\mathrm{Da}^{\mathrm{ec}} \mathrm{i}$ asal Hadhramaut. Mereka sengaja datang ke Tanah Betawi di samping menjalin bisnis perdagangan juga ingin ikut serta membantu perkembangan Islam di Tanah Betawi. Diantaranya ada Habib Ahmad bin Hamzah al-Atthas, pendiri masjid di Pekojan yang hingga kini lebih dikenal

43 Kitab ini ditulis oleh Syaikh Salim al-Hadhrami dikarenakan tingginya animo masyarakat yang ingin mempelajari dasar-dasar pokok agama dan aturanaturan fiqih yang pokok dan mendasar sesuai dengan ajaran agama Islam, sementara kitab yang mengkaji secara sistematik tentang masalah ini sangat minim sekali bahkan sempat mengalami kekosongan di pasaran. Oleh karena itu, kitab ini di tulis secara sistematik yang terdiri dari beberapa pasal mengenai pengetahuan dasar-dasar pokok agama dan aturanaturan fiqih yang pokok dan mendasar sesuai dengan ajaran agama Islam, yang menjadi suatu kewajiban umat muslim untuk mengetahuinya dan menjalankannya dalam bentuk praktek ritual keagamaan di kehidupan sehari-harinya. Kitab ini sejak pertama kali terbit dan beredar di pasaran, langsung diburu oleh kalangan para pencinta ilmu fiqih terutama yang menganut madzhab Imam Syafie $i$. Kitab ini dikenal luas diberbagai negara tidak hanya di lingkungan masyarakat Betawi atau masyarakat Melayu saja, tetapi juga di negaranegara yang menjadi basis penganut Madzhab Syafie I lainnya seperti; Yaman, Mekkah, Madinah, Jeddah, Somalia, Ethiopia, Tanzania, Kenya, Zanjibar, dan dibeberapa belahan Negara di benua Afrika. Kitab ini sampai sekarang masih diterbitkan dan beredar di pasaran.

${ }^{44}$ L.W.C Van Den Berg, Le Hadramout et les colonies Arabes dans „I"Archipel Indien, diterjemahkan oleh Rahayu Hidayat, Hadramaut dan Koloni Arab di Nusantara, Jilid 3 (Jakarta: INIS, 1989), h. 105-106. 
sebagai "Zawiyah Bin Hamzah" (Sudut/Pojok Bin Hamzah). Masjid itu dikenal dengan nama demikian karena Tokohnya banyak melakukan i"tikaf dengan berbagai kegiatan keagamaan di dalamnya. Hingga kini masjid ini terus dimakmurkan oleh jama'ahnya dengan disertai berbagai kegiatan keagamaan. Salah satunya yang paling ramai adalah ketika khatam al-Quran dalam Tarawih, yaitu setiap malam 27 Ramadhan. Lalu ada Syaikh Sa"id bin Salim Na"um, pendiri masjid Langgar Tinggi di Pekojan. sebagaimana Zawiyah Bin Hamzah, masjid ini pun sejak dahulu hingga sekarang masih terus dimakmurkan oleh Jamaeahnya dengan berbagai macam kegiatan keagamaan. Dan masih banyak lagi dari saudagar-saudagar Arab yang datang ke Tanah Betawi disamping menjalin bisnis perdagangan juga ingin ikut serta membantu perkembangan Islam di Tanah Betawi hingga dipenghunjung akhir abad ke-19 $\mathrm{M}^{45}$

Kemudian memasuki awal abad XX, di Batavia ada beberapa ulama Arab cukup terkenal asal Hadramaut yang secara khusus bergelut di dalam bidang dakwah Islamiyah, yang mayoritas dari mereka adalah kaum peranakan Arab-Indonesia. Diantaranya ada Sayyid Utsman bin Abdullah bin Yahya. Ia adalah seorang ahli fiqih yang dikenal masyarakat sebagai Mufti Betawi dan juga merupakan kawan dari seorang orientalis Barat yang bernama C. Snouck Hurgronje yang sama-sama bekerja sebagai penasehat Pemerintah Belanda untuk urusan Arab-Indonesia. Ia merupakan seorang ulama yang cukup produktif banyak menulis artikel, kitabkitab fiqih maupun Tauhid yang banyak menjadi rujukan umat muslim ketika itu, diantara karyanya yang cukup fenomenal yakni, kitab al-Qawanin asy-syar"iyyah $l i$ ahl al-majlis al-hukmiyyah wa al-

45 "Ulama Hadhrami di Tanah Betawi: Berdakwah dengan Sepenuh Hati”. Majalah alKisah Edisi 26 tahun 2013, h. 32. ifta"iyyah, ${ }^{46}$ Ishlah al-Hal bi Thalab alHalal $^{47}$ dan kitab Tauhid sifat 20 yang hingga kini masih banyak digunakan dikalangan santri-santri di pondokan ataupun di masjid-masjid maupun di majelis-majelis taklim yang dibina oleh Kyai, Ustadz ataupun para Habaib. ${ }^{48}$

Kemudian ada Habib Ali bin Abdurrahman al-Habsyi yang lebih dikenal dengan sebutan Habib Ali Kwitang. Ia adalah salah satu murid dari Sayyid Utsman bin Abdullah bin Yahya dan juga merupakan seorang pendiri masjid dan juga majelis taklim pertama di Betawi. Ia juga mendirikan sebuah madrasah yang diberi nama Unwanul Falah. Pengaruh Habib Ali Kwitang di kalangan muslimin pribumi khususnya masyarakat Betawi sangatlah besar dan tercatat di dalam kitab sejarah Tajul A"ras karangan al-Habib Ali bin Husein al-Attas Jilid 2 halaman 183 yang dikutip dan diterjemahkan oleh Abdul Qadir Umar Mauladdawilah dalam bukunya yang berjudul: 17 Habaib Berpengaruh di Indonesia, "...Dakwah al-Habib Ali bin Abdurrahman al-Habsyi telah memenuhi

46 Kitab ini ditulis karena dilatarbelakangi oleh rasa keperihatinan Sayyid Utsman akan kondisi peradilan pada masanya, penguasaan para Hakim dan penghulu akan hukum peradilan Islam masih sangat terbatas, bahkan sering terjadi prilaku penyimpangan-penyimpangan dalam pengambilan keputusan hukum di lembaga peradilan. Oleh karena itu, kitab ini ditulis berisikan khusus pedoman dan tuntunan praktis yang sangat dibutuhkan bagi para hakim dan penghulu ketika akan menjalakan perannya di tengah masyarakat. Kitab ini masih tersimpan di Perpustakaan Nasional Republik Indonesia.

47 Kitab ini ditulis karena dilatarbelakangi oleh rasa keperihatinan Sayyid Utsman akan terjadinya prilaku tidak baik di masyarakat, terutama di lingkungan masyarakat Arab dalam memperoleh mata pencaharian hidup. Ketika itu marak sekali perbuatan maksiat, riba, tipu-menipu dan pekerjaan sebagai rentenir di lingkungan masyarakat. Oleh karena itu, dalam kitab ini berisikan pasal-pasal yang menerangkan kepada masyarakat tentang perbuatan halal dan haram, terutama dalam memperoleh mata pencaharian hidup. Kitab ini masih tersimpan di Perpustakaan Nasional Republik Indonesia.

48 C. Snouck Hurgronje, De Islam in Nederlandsch Indie. V.G.IV ii (Kurt Schroeder and Leipzig, 1924), h. 75 . 
telinga-telinga kaum Muslimin, sebagaimana kitab-kitab al-Habib Utsman bin Yahya yang telah memenuhi rumahrumah mereka..." ${ }^{49}$ Hal ini terbukti dengan banyaknya ia mencetak beberapa ulama terkenal di Betawi diantaranya; $\mathrm{KH}$. Abdullah Syafieei, KH. Tohir Rohili. Mu'alim KH. Syafiee I Hadzami, KH. Fatullah Harun dan masih banyak lagi ulama-ulama terkenal betawi yang juga pernah belajar kepadanya. Dan kebanyakan dari mereka berhasil mendirikan kembali madrasah, perguruan Islam serta majelismajelis taklim seperti gurunya yang tersebar di wilayah Betawi. ${ }^{50}$

Kemudian ada dua ulama Arab di Betawi yang juga tidak kalah terkenalnya di lingkungan masyarakat Betawi mereka adalah al-Habib Ali bin Husein al-Atthas atau yang lebih dikenal dengan sebutan Habib Ali Bungur dan al-Habib Salim bin Ahmad bin Jindan. Keduanya merupakan rekan Dakwah al-Habib Ali bin Abdurrahman al-Habsyi, hampir disetiap kesempatan ketiganya berkumpul dalam setiap acara-acara pengajian, pertemuan rapat ataupun sidang-sidang penting yang menyangkut kemaslahatan umat, baik yang diselenggarakan oleh mereka masingmasing, pejabat pemerintahan maupun oleh masyarakat Betawi pada umumnya. Sehingga ada sebagian masyarakat Betawi menyebut ketiganya sebagai ulama Tiga Serangkai Betawi, bukan saja karena eratnya hubungan kedekatan mereka bertiga, tetapi juga karena hampir semua ulama Betawi yang pernah belajar dengan Habib Ali Kwitang, juga belajar kepada Habib Ali Bungur dan Habib Salim bin Ahmad bin Jindan. ${ }^{51}$

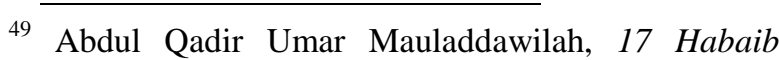
berpengaruh di Indonesia (Malang: Pustaka Bayan, 2010), h. 150

50 Rakhmad Zailani Kiki, ISLAM IBUKOTA: dari Kramtung hingga ke Brussels (Jakarta: Jakarta Islamic Center, 2009), h. 200.

${ }^{51}$ Ahmad Fadli HS, ULAMA BETAWI: Studi Tentang Jaringan Ulama Betawi dan Kontribusinya Terhadap Perkembangan Islam Abad ke-19 dan 20 (Jakarta: Manhalun Nasyi-in Press, 2011), h. 70.
Demikianlah masih ada banyak lagi dari beberapa komponen masyarakat Arab imigran ataupun peranakan, terutama dari kalangan ulama seperti Syaikh, Sayyid atau Habaib yang datang secara khusus untuk mendakwahkan Islam kepada penduduk Nusantara ataupun mereka yang sengaja datang disamping menjalin bisnis perdagangan, juga ingin ikut serta membantu tersyiarnya ajaran agama Islam, khususnya di tanah Betawi.

Cara mereka menyampaikan ajarannya pun beragam, ada yang menggunakan metode ceramah, pendekatan budaya, dan ada pula yang menggunakan metode pengajaran salafiyah atau halaqah. Khusus yang menggunakan metode terakhir ini biasanya diperuntukan bagi penuntut yang ingin mendalami ilmu keagamaan. Dan sesuai dengan metode yang digunakan, pengajaran yang mereka lakukan itu ada yang bersifat massal dan ada pula yang bersifat khusus, bahkan ada yang mengajar secara privat. ${ }^{52}$

Adapun tempat mereka untuk menyampaikan ajarannya pun beragam, ada yang di rumah-rumah, di langgar, mushalah, masjid-masjid, majelis taklim ataupun madrasah-madrasah yang mereka dirikan. Hingga kini diberbagai tempat di Betawi semakin banyak pengajianpengajian yang dipimpin oleh orang-orang Arab Hadhramaut, yang memegang peranan penting dalam mencetak ulama dan memperkukuh dakwah Islamiyah di tanah Betawi.

\section{PENUTUP}

Peranan komunitas Arab dalam bidang sosial-keagamaan sangatlah besar bagi perkembangan Islam di Tanah Betawi. dimulai dengan peranan yang di mainkan oleh Sayyid Husein bin Abu Bakar alAidrus. Melalui sebuah mushalah kecil yang didirikanya, ia mengabdikan diri dan ilmu yang dimilikinya kepada masyarakat hingga akhir hayatnya. Hal serupa ini pun terus dilakukan oleh generasi seterusnya,

\footnotetext{
52 Abdul Aziz, Islam dan Masyarakat Betawi (Jakarta: PT. Logos Wacana Ilmu. 2002), h. 144.
} 
seperti; Syaikh Salim bin Abdullah bin Sa'ad bin Sumair al-Hadhrami, Sayyid Abdurrahman bin Abu Bakar al-Habsyi, Habib Ahmad bin Hamzah al-Atthas, dan Syaikh Sa'id bin Salim Na'um. Meskipun diantara mereka adalah para saudagarsaudagar kaya yang datang untuk menjalin bisnis perdagangan, namun mereka juga ikut serta membantu perkembangan Islam di tanah Betawi, tentunya didukung dengan kekayaan yang dimilikinya.

Peranan ini semakin terlihat ketika memasuki awal abad XX, dimana peranan ini mayoritas dimainkan oleh kaum peranakan Arab-Indonesia, diantaranya ada Sayyid Utsman bin Abdullah bin Yahya, Habib Ali bin Abdurrahman al-Habsyi, Habib Ali bin Husein al-Atthas dan Habib Salim bin Ahmad bin Jindan. jasa mereka sangat besar bagi masyarakat Betawi, melalui perantara mereka lahir ulama-ulama Betawi tersohor dan melalui perantara mereka pula berdirilah lembaga-lembaga pendidikan Islam serta majelis-majelis taklim di tanah Betawi yang terus berkembang hingga saat ini, yang keberadaanya semakin memperkukuh keimanan dan keislaman masyarakat Betawi. Begitupun dengan berdirinya organisasi modern yang bernama Jamiat Kheir di awal abad XX. Organisasi ini terkenal bukan saja karena keberhasilannya mendirikan sekolah-sekolah Islam modern pertama yang melahirkan tokoh-tokoh penting di negeri ini, tetapi juga karena kegiatan-kegiatan sosial-keagamaannya yang diwujudkan dalam bentuk pendirian beberapa panti asuhan, Islamic center, percetakan dan juga fasilitas umum seperti; perpustakaan, masjid dan rumah sakit. Wujud nyata itupun masih bisa disaksikan dan masih berlanjut hingga kini dalam program kegiatan-kegiatan yang dilaksanakan oleh ar- Rabithah alAlawiyyah. Oleh karena itu, berdasarkan fakta-fakta yang ada tersebut, pernyataan Van den Berg, dkk, bahwa tak seorang Arab pun datang ke Nusantara hanya untuk bertujuan menyebarkan agama, berdagang dan mencari keuntungan materi merupakan tujuan utama mereka, ini sangat tidak dibenarkan.

Menurut keterangan yang penulis dapatkan dari berbagai sumber, mengapa mereka mengeluarkan pernyataan demikian, disamping karena tidak terlepas dari kedudukan mereka sebagai pegawai pemerintah kolonial, yang memiliki tugas untuk menghilangkan pengaruh Arab (Islam) dari masyarakat pribumi guna mempertahankan jajahannya, juga karena kurangnya pengetahuan mereka tentang konsep dagang Islam serta latar belakang budaya dan mentalitas bangsa Arab. Sehingga mengakibatkan mereka sulit untuk menditeksi misi yang tersirat dibalik fenomena yang tampak dihadapan mereka. Selain itu menurut hasil analisis penulis, hal ini dikarenakan mereka terlalu cepat menjustifikasikan semua orang Arab seperti itu, tanpa melakukan analisis kesimpulan yang lebih mendalam.

\section{DAFTAR PUSTAKA}

\section{Arsip, Manuskrip dan Dokumen}

al-Alawi, Sayyid Utsman bin Abdullah bin Yahya, "al-Qawanin asy-syar"iyyah li ahl al-majlis al-hukmiyyah wa alifta "iyyah." diterjemahkan ke dalam bahasa Indonesia dengan judul, "Ini kitab segala aturan hukum syara bagi ahli majlis syara dan majlis fatwa syara." Batavia: Percetakan Sayyid Utsman, 1881 M/1317 H.

, "Ishlah al-Hal bi Thalab alHalal." Batavia: Percetakan Sayyid Utsman, t.t. 
Arsip Nasional RI, Regeerings-Almanak voor Nederlandsch-Indie, 18181879. Batavia: Landsdrukkerij.

Staadsblad van Nederlandsch-Indie 1816 Nomer 47.

Gobee, E. dan C. Adriaanse, Ambtelijke adviezen van C. Snouck Hurgronje 1889-1936"s Gravenhage:Nijhoff. (Rijks Geschiedkundige Publicatien, Kleine Serie 33, 34, 35), diterjemahkan ke dalam bahasa Indonesia dengan judul, "NasihatNasihat C. Snouck Hurgronje Semasa Kepegawaiannya Kepada Pemerintah Hindia-Belanda 1889. 1936.” Vol. IX. Jakarta: INIS, 1990.

al-Hadhrami, Syaikh Salim bin Abdullah bin Sa'ad bin Sumair, "Safinatun Najah Fiima Yajibu ,ala Abdi li Maulah.” Batavia: T.pn., abad 13 H/19 M.

Hurgronje, C. Snouck. Verspreide Geschriften van C. Snouck Hurgronje (Bonn dan Leipzig: Kurt Schroeder, 1924), diterjemahkan ke dalam bahasa Indonesia dengan judul, “Kumpulan Karangan Snouck Hurgronje." vol. IX. Jakarta: INIS, 1993.
Nederlandsch Indie." V.G.IV ii Kurt Schroeder and Leipzig, 1924.

Shahab, Ali Abu Bakar. "ar-Rabithah alAlawiyyah.” Batavia: koleksi Pribadi, 1928.

\section{Buku}

Assegaf, M. Hasyim. Derita Putri-Putri Nabi. Bandung: PT. Remaja Rosdakarya, 2000.

Aziz, Abdul. Islam dan Masyarakat Betawi. Jakarta: PT. Logos Wacana Ilmu, 2002.

Azra, Prof. Dr, Azyumardi. Islam Nusantara: Jaringan Ulama Global dan Lokal. Bandung: Mizan, 2002.

Berg, L.W.C. van den. Le Hadramaut et. les Colonies Arabes Dans L"Archipel Indien. (Batavia: Imprimerie du Gouvernement, 1886). Terjemahan, Rahayu Hidayat. Hadramaut dan Koloni Arab di Nusantara, Jilid 3. Jakarta: INIS, 1989.

Castle, Lance, The Ethnic Profile of Djakarta. New York: Cornell University, 1967. 
Cortesao, Armando. The Suma Oriental of Tome Pires: An Account of the East From Read Sea to Japan, Writen in Malaka and India 1512-1644, Vol.

2. London: The Hakluyt Sosiety, 1994.

Darmawijaya. Kesultanan Islam Nusantara. Jakarta: Pustaka Al-Kautsar, 2010.

Fadli HS, Ahmad ULAMA BETAWI: Studi Tentang Jaringan Ulama Betawi dan Kontribusinya Terhadap Perkembangan Islam Abad ke-19 dan 20. Jakarta: Manhalun Nasyi-in Press, 2011.

al-Gadri, Hamid. Politik Belanda Terhadap Islam dan Keturunan Arab di Indonesia. Jakarta: CV. Haji Masagung, 1988.

Gottschalk, Louis. Mengerti Sejarah. terjemahan Nugroho Notosusanto. Jakarta: Universitas Indonesia Press, 1983.

al-Haddad, Alwi bin Thahir. Sejarah Masuknya Islam di Timur Jauh, Cet. 3. Jakarta: PT. Lentera Basritama, Cet, 1997.
Hasjmy, Prof. Dr, Ahmad. Sejarah Masuk dan Berkembangnya Islam di Indonesia. Bandung: Al-Ma'arif, 1981.

Hendropuspito, D. Sosiologi Sistematik. Yogyakarta: Kanisius, 1989.

Sosiologi Agama, Yogyakarta: Kanisius, 1989.

Jonge, Huub De and Kaptein, Nico. Trancending Borders: Arabs, Politics, Trade and Islam in Southeast Asia. Leiden: KITLV Press, 2002.

Kesheh, Natalie Mobini. Hadrami Awakening: Kebangkitan Hadhrami di Indonesia. Jakarta: Akbar, 2007.

awakening, community and identity in the Netherlands East Indies, 1900-1942. New York: Cornell Southeast Asia Program Publications, 1999.

Kiki, Rakhmad Zainal. ISLAM IBUKOTA: dari Kramtung hingga ke Brussels. Jakarta: Jakarta Islamic Center, 2009. 
al-Masyhur, Idrus Alwi. Sejarah, Silsilah dan Gelar Keturunan Nabi Muhammad SAW. Di Indonesia, Singapura, Malaysia, Timur Tengah, India dan Afrika, Cet. 2. Jakarta: Saraz Publishing, 2010.

Mauladdawilah, Abdul Qadir Umar. 17 Habaib berpengaruh di Indonesia. Malang: Pustaka Bayan, 2010.

Noer, Deliar. Gerakan Modern Islam di Indonesia 1900-1942, Cet. 8. Jakarta: PT. Pustaka LP3ES, 1996.

Notosusanto, Nugroho. Hakekat Sejarah dan Metode Sejarah. Jakarta: Mega Book Store, 1984.

Peter J.M and Kees Grijns. Jakarta Batavia: Socio-Cultural essay. Terj. Gita Widya Laksmini dan Noor Cholis. Leiden: KITLV Press and Banana, 2000/2007.

Pijper, G.F. Studien over de Geschiedenis van de Islam in Indonesia 19001950. Terjemahan, Tudjimah dan Yessy Augusdin. Beberapa Studi tentang Sejarah Islam di Indonesia 1900-1950. Jakarta: UI-Press, 1985.
Renier, G.J. Metode dan Manfaat Ilmu Sejarah. terjemahan Muin Umar. Yogyakarta: Pustaka Pelajar, 1997.

Saidi, Ridwan, Orang Betawi dan Modernisasi Jakarta. Jakarta: LSIP, 1994.

Shahab, Alwi. Islam Inklusif: menuju sikap terbuka dalam beragama. Bandung: Mizan, 1998.

Soekanto, Soejono. Sosiologi Suatu Pengantar. Jakarta: PT. Grafindo Persada, 2006.

Sugiyono, Metode Penelitian Kualitatif, dan R\&D. Bandung: Alfabeta, 2006.

Suminto, Aqieb. Politik Islam HindiaBelanda. Jakarta: LP3ES, 1986.

Suryabrata, Sumadi, Metode Penelitian. Jakarta: CV. Rajawali, 1989.

Tjandrasasmita, Uka. Pertubuhan dan Perkembangan Kota-Kota Muslim di Indonesia. Kudus: Menara Kudus, 2000.

Weber, Max. Die Protestantische Ethik und der Geist des Kapitalismus. terjemahan, Yusup Priyasudiarja. Etika Protestan dan Semangat 
Kapitalisme. Surabaya: Pustaka Promethea, 2000.

\section{Artikel Website dan Journal}

Abushouk, Ahmad Ibrahim. "al-Man"ar and the Hadhrami Elite in the Malay-Indonesian World: Challenge and Response." United Kingdom: Journal Of The Royal Asiatic Society, 2007.

Jamroni, "Masjid Bersejarah di Jakarta." Jurnal al-Turas Vol. 12 No.2, Fakultas Adab dan Humaniora UIN Syarif Hidayatullah, Jakarta. 2006.

"Mindoro." Sejarah Jakarta. Artikel diakses pada 4 Agustus 2014 dari http://www.jakarta.go.id/web/encycl opedia/detail/168/batavia.

\section{Majalah Terbitan Berkala}

Azra, Prof. Dr, Azyumardi. "Hadhrami Scholars in the Malay-Indonesian Diaspora." Studia Islamika, Vol.2, No. 2, I.A.I.N. Syarif Hidayatullah, Jakarta, 1995.

Majalah al-Kisah, "Ulama Hadhrami di Tanah Betawi: Berdakwah dengan Sepenuh Hati." Majalah al-Kisah Edisi 26 tahun 2013.
Majalah ar-Rabithah al-Alawiyah. " 80 Tahun Daarul Aitam; Mengelola Anak ,Titipan" Rasulullah SAW." Yayasan ar-Rabithah al-Alawiyah Daarul Aitam, Jakarta, 2011.

\section{Skripsi, Tesis dan Desertasi}

Haikal, Husein. "Indonesia-Arab dalam Pergerakan Kemerdekaan Indonesia (1900-1942)." Desertasi Phd, Univesitas Indonesia, 1986.

Julianri. "Persatuan di kalangan Masyarakat Arab Indonesia." Skripsi Sarjana Sastra Jurusan Sejarah Fakultas Sastra Universitas Indonesia. Jakarta. 1987.

Shahab, Yasmin Zacky. "Masalah Integrasi Minoritas Arab di Jakarta." Skripsi Sarjana Antropologi Fakultas Sastra Universitas Indonesia. Jakarta, 1975. 
